\title{
THE EFFECT OF DELAYED FERTILIZATION IN SOME SPECIES OF THE GENUS TISBE (COPEPODA, HARPACTICOIDA)
}

\author{
BRIGITTE VOLKMANN-ROCCO
}

\author{
Istituto di Biologia del Mare, CNR, Venice, Italy
}

Sex-determination in Copepods appears to be rather complex and in most cases still obscure. Two types may, however, be clearly distinguished, namely, environmental and genetic determination of sex.

Takeda (1950) and Egami (1951) reported that external conditions, such as chemical agents and temperature, were sex controlling factors for the harpacticoid copepod, Tigriopus japonicus. A similar influence of temperature was observed by Battaglia (1959a) in natural populations of Porcellidium.

Later a polygenic control of the sex-ratio was proposed for Tigriopus (Ar-Rushdi, 1958).

In copepods of the genus Tisbe experiments of inbreeding and selection suggested a genetic determination of sex. In fact, it was found that in $T$. gracilis and $T$. reticulata inbreeding produces a strong increase of males and that selection towards males is always effective, but apparently ineffective towards females (Battaglia, 1958; Battaglia and Malesani, 1959; 1962). On the basis of these and other observations a hypothesis was advanced that in Tisbe sex is determined by a multifactorial system consisting of several dominant factors for femaleness $(\mathrm{F})$ and several recessive factors for maleness $(\mathrm{m})$, not allelic and spread over various chromosomes. The full expression of factors F appears to be conditioned by their heterozygous state, whereas the maleness factors would express themselves only in the recessive homozygotes $\mathrm{mm}$. In other words, the degree of femaleness appears to be a function of the number of heterozygous loci $\mathrm{F}$ and $\mathrm{m}$; the degree of maleness would instead be a function of the degree of homozygosity of both kinds of loci.

This hypothesis - sex under the control of a multifactorial system-leads, moreover, to an understanding of the variable sex-ratio in these animals including families with a strong excess of males or of females (Battaglia, 1958; Battaglia and Malesani, 1959). Their distribution is, however, in most cases close to normal.

The above interpretation infers that only internal conditions-that is consanguinity-appear so far to affect the sex-ratio in Tisbe, where a higher proportion of males is a function of homozygosity.

Some observations made incidentally during recent investigations on two species of Tisbe (Volkmann-Rocco and Battaglia, 1971) suggest that the sex-ratio may be affected in these species by an external factor, delayed fertilization. Such an influence of the overmaturation of eggs on the sex-ratio has been proved especially in amphibians and butterflies. Thus, a series of detailed investigations was carried out, in order to obtain a wider knowledge on how a delay in fertilization might influence sex-ratio in Tisbe. 


\section{Material And Methods}

The experiments were carried out at constant temperature of $18^{\circ} \mathrm{C}$ and salinity of about $36 \%$. The material consisted of 3 species of Tisbe: T. dobzhanskii Volkmann-Rocco and Battaglia, collected in Anzio (Italy) in June 1968; T. holothuriae Humes from the Island Ponza (October 1969); T. clodiensis Battaglia and Fava, one population from the Lagoon of Venice (August 1967) and the other from the Island Ponza (October 1969). About 30 ovigerous females per species were chosen at random from cultures kept in the laboratory under standard conditions, and isolated in single dishes containing $20 \mathrm{cc}$ of filtered sea water and 0.5 cc of a suspension of Dunaliella or Platymonas. After deposition of the eggsac the females were removed and a piece of boiled wheat was added as food for the freshly hatched nauplii, according to the technique described by Battaglia (1959). The offspring were checked once every 2 days. They were used partly for the experimental and partly for the control series. When the 4 th copepodite stage was reached, control pairs were set up by putting together one female copepodite and one male from different families, while the individuals which later should provide the experimental pairs were kept isolated in order to prevent them from mating, and thus to delay fertilization of the females.

Since the life cycle differs more or less from species to species, the control pairs were set up at different times, namely 6 days after hatching for $T$. holothuriae, 7 days after hatching for $T$. dobzhanskii and $T$. clodiensis from Venice, and 8 days after hatching for $T$. clodiensis from Ponza. Each dish was checked once every day in order to detect mating and to discard pairs of the same sex. There is, in fact, a possibility of putting together 2 female or 2 male copepodites, since sexes may be distinguished only with difficulty at the 4th copepodite stage. When the female became ovigerous, she was transferred to a freshly prepared dish to guarantee the most favorable environment for the larvae. As soon as these hatched the female was removed and the larvae were reared as described before.

When part of the control females had become ovigerous, males and females of the experimental series, until then kept in isolation, were put together, one pair per dish. The introduction of the male was delayed as long as possible depending on the species. It was then observed if mating occurred and if the female produced an egg-sac and viable offspring. The ovigerous females were transferred to a new dish, as described for the controls, and removed soon after the deposition of an egg-sac. When the offspring had become adult, they were counted and sexed; the same procedure was adopted for the offspring of the controls.

The control series will be referred to as sample $\mathrm{C}$, the experimental series as sample E.

A statistical analysis and comparison of the mean sex-ratios of samples $\mathrm{C}$ and $\mathrm{E}$ was carried out with the chi-square test. However, this was not considered sufficient, because of the heterogeneity of the sex-ratio data. In order to exclude heterogeneity from the calculations and to have a better statistical evaluation of the differences between control and experimental series, only the families significantly shifted in favor of males were taken in consideration and compared with the $\chi^{2}$-test.

Significance of the sex-ratio of each family was calculated by individual chisquare test. Because of the complex and still obscure mechanisms of sex-deter- 
mination in Tisbe, the expected frequencies could not be based on an extrinsic hypothesis. Thus, the null hypothesis has been extracted from the control series.

For $T$. dobzhanskii a ratio of $42 \%$ females was taken as null hypothesis, a value which agrees well with previous observations (Volkmann-Rocco and Battaglia, 1971).

For T. clodiensis from Venice a sex-ratio of $47.5 \%$ females was used as expected value coinciding rather well with observations made by Lazzaretto-Colombera and Polo (1969) and by Fava (Istituto di Biologia del Mare, CNR, Venezia personal communication).

For T. clodiensis from Ponza the ratio used in the null hypothesis was $41 \%$ females, and for T. holothuriae, $45 \%$.

Families containing less that 20 individuals were discarded to exclude errors due to differenial mortality, the number of these families was however low and is reported later.

\section{Results}

Tisbe dobzhanskii (from Anzio)

In T. dobzhanskii from Anzio the average time between hatching of the nauplii and egg-sac production was observed to be 10-11 days, thus confirming recent findings by Volkmann-Rocco and Battaglia (1971).

Thirteen days after hatching, when the females of the controls had become ovigerous and in part had already given offspring, the isolated males and females were put together, one pair for each dish. Within the first 20 minutes many of the 46 pairs were found copulating. In all cases the females extruded an egg-sac on the following day, that is, 14 days after hatching. Males and females of the experiment had been kept isolated for 6 days, thus mating was delayed for about 5 days and egg-sac production for 3-4 days compared with the controls.

From 40 control pairs 3 females produced an egg-sac which did not develop; one family containing very few individuals was discarded. The sex-ratio of the offspring of the remaining 36 pairs was calculated to be $41.12 \%$ of. The average number of females and males per family were 19.9 and 28.5, respectively. These values are, however, only suggestive. As we see from Table I there is a great heterogeneity in the various families. In some families a strong shifting of the sex-ratio in favor of males or females was observed; namely, in about $27 \%$ of the families it was significantly shifted in favor of males; in about $22 \%$ in favor of females (Table I).

From the 46 females kept in isolation for 13 days, 3 produced an egg-sac which failed to hatch; one was discarded because of the low number of offspring. From the remaining 42 families, 421 females and 1841 males were obtained, corresponding to a sex-ratio of $18.61 \%$ of . Differential mortality may be excluded, since the average number of offspring per female (53.8 individuals) did not drop, but slightly increased. A comparison between this value and the sex-ratio of the controls yielded a highly significant value of the chi-square with $P<0.001$ (Table II). Although, as mentioned above, the progeny were not homogeneous, a comparison could be easily carried out between samples $\mathrm{C}$ and $\mathrm{E}$ by comparing the numbers of teligenous and arrhenogenous families. In sample $\mathrm{E}, 73.8 \%$ of 
the families had a sex-ratio which was statistically significant in favor of males (Table I). A comparison with the $27.7 \%$ of arrhenogenous families of sample C yielded $\chi^{2}=16.483(P<0.001)$.

\section{T. clodiensis (from Venice)}

For $T$. clodiensis from the Lagoon of Venice the time between hatching of the nauplii and egg-sac production was found to be 12-13 days coinciding with the results obtained by Lazzaretto-Colombera and Polo (1969).

\section{TABLE I}

Percentages of families with a sex-ratio $(A)$ not significant by individual $\chi^{2}$ test,

$(B)$ significantly shifted towards females, and (C) significantly shifted towards males without (Control) and after artificially delayed

fertilization (Experiment)

\begin{tabular}{|c|c|c|c|c|c|c|c|}
\hline & & \multicolumn{3}{|c|}{ Control } & \multicolumn{3}{|c|}{ Experiment } \\
\hline & & $\begin{array}{c}\% \\
\text { Families }\end{array}$ & Range $\%$ \& $\%$ & 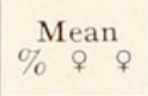 & $\begin{array}{c}\% \\
\text { Families }\end{array}$ & Range $\%$ \& $\%$ & $\begin{array}{l}\text { Mean } \\
\% \text { \& } q\end{array}$ \\
\hline T. dobzhanskii from Anzio & A & 50.00 & $29.8-55.8$ & 41.1 & 19.09 & $29.4-50.6$ & 40.0 \\
\hline $\mathrm{C}=36$ families & $\mathrm{B}$ & 22.23 & $58.8-73.3$ & 66.3 & 7.10 & $58.1-66.6$ & 62.0 \\
\hline $\mathrm{E}=42$ families & $\mathrm{C}$ & 27.77 & $17.0-28.1$ & 22.3 & 73.80 & $0.0-26.0$ & 9.4 \\
\hline$T$. clodiensis from Venice & A & 65.85 & $34.3-58.8$ & 47.3 & 58.92 & $33.3-59.2$ & 43.2 \\
\hline $\mathrm{C}=41$ families & $\mathrm{B}$ & 19.51 & $62.7-90.0$ & 73.5 & 8.92 & $62.7-70.0$ & 77.4 \\
\hline $\mathrm{E}=56$ families & $\mathrm{C}$ & 14,63 & $0.0-25.8$ & 11.9 & 32.14 & $0.0-31.2$ & 17.4 \\
\hline T. clodiensis from Ponza & $\mathrm{A}$ & 55.17 & $27.7-50.0$ & 39.1 & 38.77 & $29.0-53.0$ & 38.38 \\
\hline $\mathrm{C}=29$ families & B & 24.13 & $55.3-83.3$ & 62.9 & 14.28 & $53.3-82.4$ & 62.7 \\
\hline $\mathrm{E}=49$ families & $\mathrm{C}$ & 20.68 & $9.0-24.4$ & 17.6 & 46.93 & $1.8-27.3$ & 14.0 \\
\hline T. holothuriae from Ponza & A & 37.93 & $31.1-55.1$ & 43.8 & 36.95 & $33.3-55.5$ & 43.5 \\
\hline $\mathrm{C}=29$ families & $\mathrm{B}$ & 37.93 & $60.8-84.7$ & 68.8 & 19.56 & $62.5-95.1$ & 72.3 \\
\hline $\mathrm{E}=46$ families & $\mathrm{C}$ & 24.13 & $10.2-29.6$ & 19.5 & 43.47 & $0.0-30.1$ & 13.1 \\
\hline
\end{tabular}

Since the isolated non-fertilized females were full of eggs which hardly seemed to be retained in the oviducts, the experimental pairs were set up 13 days after hatching. Previous tests had shown that unfertilized females kept too long in isolation were no longer able to extrude an egg-sac and to produce viable offspring, even though mating occurred. In some cases the females were, however, prevented from mating, since they had extruded very few eggs. A complete egg-sac was never produced without copulation, as it has been observed in other species of Tisbe. For T. clodiensis from Venice 13 days seemed to be a limit for normal mating to insure a high percentage of offspring. Forty-seven pairs out of 71 were observed mating within the first 20 minutes. Fifty females extruded their egg-sac on the following day, that is, 14 days after hatching. In sample E, females and males had been kept 6 days longer in isolation than the control pairs; although mating occurred 4-5 days later, egg-sac production was delayed only about 2 days 
From 51 control pairs 3 females produced an egg-sac in which the eggs failed to hatch and seven females were discarded because of the low number of offspring. The sex-ratio of the progeny produced by 41 control females was calculated to be $47.29 \%$ oq ( 716 females and 798 males). Also in this case the data are heterogeneous (Table II).

From 71 pairs of sample $\mathrm{E}$ the progeny of 56 was considered for a statistical evaluation of the data, since 10 families contained less than 20 individuals. Three females produced an egg-sac, in which the eggs failed to hatch, and 2 females did not extrude an egg-sac. The offspring of the 56 females showed a clear tendency towards an increase of males, that is, 1096 females and 1709 males. As expected in view of the consistent trend in favor of males, a comparison between the sex-

TABLE II

Comparison between the mean sex-ratios of the control $(C)$ and experimental $(E)$ series

\begin{tabular}{|c|c|c|c|c|}
\hline & No. of families & Total No. adults & $\%$ \& & $\begin{array}{l}\text { Comparison } \\
\text { between } \\
\text { sex-ratios }\end{array}$ \\
\hline $\begin{array}{l}\text { T. dobzhanskii from Anzio } \\
\text { C } \\
\text { E }\end{array}$ & $\begin{array}{l}36 \\
42\end{array}$ & $\begin{array}{l}1741 \\
2262\end{array}$ & $\begin{array}{l}41.12 \\
18.61\end{array}$ & $\begin{array}{l}\chi^{2}=244.092 \\
P<0.001\end{array}$ \\
\hline $\begin{array}{l}\text { T. clodiensis from Venice } \\
\text { C } \\
\text { E }\end{array}$ & $\begin{array}{l}41 \\
56\end{array}$ & $\begin{array}{l}1514 \\
2805\end{array}$ & $\begin{array}{l}47.29 \\
39.08\end{array}$ & $\begin{array}{l}\chi^{2}=27.273 \\
P<0.001\end{array}$ \\
\hline $\begin{array}{l}\text { T. clodiensis from Ponza } \\
\text { C } \\
\text { E }\end{array}$ & $\begin{array}{l}29 \\
49\end{array}$ & $\begin{array}{l}1441 \\
2732\end{array}$ & $\begin{array}{l}40.87 \\
30.01\end{array}$ & $\begin{array}{l}\chi^{2}=49.751 \\
P<0.001\end{array}$ \\
\hline $\begin{array}{l}\text { T. holothuriae from Ponza } \\
\text { C } \\
\text { E }\end{array}$ & $\begin{array}{l}29 \\
46\end{array}$ & $\begin{array}{l}1493 \\
2770\end{array}$ & $\begin{array}{l}45.14 \\
37.43\end{array}$ & $\begin{array}{l}\chi^{2}=25.140 \\
P<0.001\end{array}$ \\
\hline
\end{tabular}

ratio of samples $\mathrm{E}$ and $\mathrm{C}$ yielded a chi-square $=27.273(P<0.001)($ Table II $)$.

Shifting of the sex-radio towards males was observed in $32.1 \%$ families of sample E, whereas in the control series only $14.6 \%$ had a significant increase of males (Table I). For these data $\chi^{2}=3.887(P<0.005)$ was obtained. Comparing the average number of males and females per family of samples $\mathrm{C}$ and $\mathrm{E}$, respectively, 36.9 and 50.1 individuals, an increase of 13 individuals per family in sample E was observed, largely due to the greater number of males.

\section{T. clodiensis (from Ponza)}

In the other population of $T$. clodiensis, the average time between hatching of the nauplii and egg-sac production was observed to be 12-13 days. When nearly all females of sample $\mathrm{C}$ had become ovigerorus, that is, 13 days after hatching, the isolated males and females were put together, one pair for each dish. Thirtyfour pairs out of 60 were observed mating within the first 20 minutes; subsequently fifty-four females extruded an egg-sac on the following day, that is, 14 days after 
hatching. Thus, males and females of sample $\mathrm{E}$ had been kept isolated about 5 days longer than the controls. Although mating occurred about 4 days later, egg-sac production was delayed for only two days, as it had been observed for T. clodiensis from Venice.

From 33 control pairs, 2 produced an egg-sac which did not develop, one female extruded no egg-sac, and one gave very few offspring. The sex-ratio of the remaining 29 families was calculated to be $40.87 \%$ of , that is, 589 females and 852 males (Table II).

From the 54 females of sample $\mathrm{E}$ the progeny of 49 could be utilized for statistical analysis, since one female did not extrude egg-sacs, 2 gave a reduced number of offspring and 2 others produced egg-sacs, the eggs of which failed to hatch. From 49 families, 820 females and 1912 males were obtained, corresponding to a sex-ratio of $30.01 \%$ ofo. Differences between the number of males and females of the control and experimental series yielded a highly significant chi-square value (Table II).

In $46.9 \%$ of the families of sample $\mathrm{E}$ the sex-ratio was shifted in favor of males, while in sample C only $20.6 \%$ showed an increase of males (Table I). A comparison of the precentages gave $\chi^{2}=5.379$ and $P<0.02$. The average number of individuals per family was somewhat higher in sample $E$ ( 6 individuals), but less than in the case of $T$. clodiensis from Venice.

In order to detect what happens if fertilization is delayed still more, 18 virgin females were kept 14 days in isolation. Immediately after introduction of the males, copulation occurred. Two females did not produce an egg-sac, one female extruded eggs which failed to hatch and one gave very few offspring. The progenies of the remaining 14 families suggested a still greater tendency to produce males than in the experiment described above, the sex-ratio being $27.18 \%$ of But there was a slight drop in the number of individuals per family. Since the results are based on a relatively small sample a statistical evaluation of the data was omitted.

\section{T. holothuriae (from Ponza)}

For T. holothuriae from Ponza the average time between hatching of the nauplii and egg-sac production was found to be 9-10 days. When nearly all females of the controls had become ovigerous, that is, 10 days after hatching, males and females until then isolated were put together. A period of 10 days seems to be the extreme limit to guarantee normal fertilization, since of the 58 isolated females 8 had produced a small egg-sac in absence of a male 10 days after hatching, thus excluding the possibility that fertilization could still occur. After the males had been introduced only 12 pairs were found mating within the first 20 minutes. This may be due to the fact that mating time in $T$. holothuriae is short and thus, difficult to be seen. Moreover, this species is sexually less active than T. clodiensis. From the 50 females, 42 produced an egg-sac one day after introduction of the male, that is, 11 days after hatching. Thus, in the case of $T$. holothuriae the time differences between sample $\mathrm{C}$ and $\mathrm{E}$ for the moment of copulation and especially for the period of egg-sac production were remarkably reduced, being 4 and 1-2 days, respectively. 
From 32 control pairs one female produced an egg-sac which gave no offspring, and two families were discarded. The sex-ratio of the 29 families was calculated to be $45.14 \%$ females, based on a total number of 1493 individuals. The data show, however, a strong heterogeneity, $37.9 \%$ of the progeny being shifted in favor of females, $24.1 \%$ in favor of males, and $37.9 \%$ being statistically insignificant (Table I).

From the 50 females of sample E, two extruded no egg-sac, and 2 gave less than 15 female offspring. The other 46 females produced 2770 individuals yielding a sex-ratio of $37.43 \%$ of. Comparing this value with the sex-ratio of the control series a highly significant value of $\chi^{2}$ (Table II) was obtained.

In spite of the suggestive trend towards males in sample $E$, the comparison between the percentage of arrhenogenous families of sample $\mathrm{C}$ and $\mathrm{E}, 43.4 \%$ qo and $24.1 \%$ oq, respectively, does not result in a statistically significant $\chi^{2}$ value, since $P<0.10$ for $\chi^{2}=2.959$.

Also in $T$. holothuriae an increase of 9 individuals per family was recorded in sample E, entirely due to an increase in the number of males.

\section{Discussion}

Most of the present knowledge about the effects of a delayed fertilization is based on very few studies carried out with amphibians (Hertwig, 1921; Kuschakewitsch, 1923; Witschi, 1923), butterflies (Seiler, 1920).

Experiments with Rana esculenta indicated that overripeness of eggs produces complete reversal of females into males. From normal eggs $53 \%$ males were obtained, from overripe eggs fertilized 89 hours later than the controls $100 \%$ males hatched (Kuschakewitsch, 1923). Witschi (1924) attributed this sexreversal to cytoplasmic alterations that affect the medulla more than the cortex in the later part of the development.

Also in the case of the butterfly Talaeporia overripeness of eggs produces a majority of homozygous male zygotes, since it favors the permanence of the $\mathrm{X}$ chromosome in the egg. Low temperature $\left(3-5^{\circ} \mathrm{C}\right)$ has the same effect (Seiler, 1920).

Shull and Ladoff (1916) who treated the rotifer Hydatina with various substances (potassium sulfate, iron chloride, ammonium chloride, dilute bouillon) suggested that the speed of metabolic reactions is responsible for the varying degrees of male production. They assumed that male production is reduced, when the physiological processes are retarded, which they think to be the case for most agents which affect the life cycle.

Similar considerations were made by Takeda (1950) and Egami (1951) who studied the effect of external agents on the copepod Tigriopus japonicus. At the end of a long series of experiments they concluded that all suppression of metabolic activity tends to induce feminization. This would correspond to the situation dedescribed for Hydatina, but certainly not to that in Tisbe and Talaeporia, since the delay of fertilization or a low temperature may rather induce retardation of developmental processes. As the above experiments evidenced, the genus Tisbeat least the species taken in consideration-shows a more or less pronounced tendency towards masculinization in consequence of overmaturation of the eggs depending on the duration of the delay. 
In fact, in $T$. dobzhanskii where the differences concerning the moment of fertilization and egg-sac production between sample $\mathrm{C}$ and $\mathrm{E}$ were greater than in the other species, the shifting towards males was statistically highly significant. This is less evident in T. holothuriae. While in T. dobzhanskii the pairs of sample $\mathrm{E}$ had been kept isolated until nearly each female of the control series had given offspring, in $T$. holothuriae the males had to be put together with the isolated females when only half of the control females had produced an egg-sac, since the former began to extrude their eggs without being fertilized. A point which I should like to mention briefly in this context is the choice of two different populations of T. clodiensis for the experiment. Former experiments have shown that there is nearly complete reproductive isolation between some geographical populations of this species, and the fact that they differ in their life cycle parameters and polymorphism suggests that they have evolved independently. The present data produce evidence that in addition to the different sex-ratio the population of Ponza appears to be more affected by a delayed fertilization.

With too long a delay the females became unable to produce an egg-sac or extruded only very few eggs which failed to hatch (T. dobzhanskii and $T$. clodiensis), or a small egg-sac was extruded before mating occurred ( $T$. holothuriae).

The shifting of the sex-ratio in consequence of overmaturation is accompanied in Tisbe by another phenomenon, namely, increase of the number of offspring per family, largely due to the greater number of males. Thus, the number of females per family remained nearly equal in the control and the experimental series (T. clodiensis and $T$. holothuriae). This could be due to a reduced mortality in sample E, as stated for Rana esculenta, where $6 \%$ mortality was observed in the normal culture and only 4\% in the culture from overripe eggs (Kuschakewitsch, 1923). It is however, somewhat difficult and rather laborious to solve this question in Tisbe, since the eggs of an egg-sac cannot be counted without destroying the egg-sac. On the other hand, comparing the sex-ratio data, as far as it is possible, with those obtained from other experiments, it can be proved easily that the number of individuals per family in the control series was rather high or at least normal, so that differential mortality may probably be excluded.

It seems, although there is no statistical proof, that more eggs are produced when the fertilization is artificially delayed. Since the males and females of sample $\mathrm{C}$ and $\mathrm{E}$ were carefully observed when they extruded their egg-sacs, it was noticed that the egg-sacs of sample $\mathrm{E}$ were bigger. This would suggest that there is a continuous production of eggs for a time in the absence of fertilization. The oviducts of the isolated females were, in fact, filled with eggs, more so than in the case of normally fertilized females. The delay of fertilization at the beginning of the reproductive cycle seems to affect also the production of the second egg-sac. Fifteen females of $T$. holothuriae and 17 females of $T$. clodiensis from Venice (sample E) were kept until they had produced a second egg-sac. The results, which are too few to be statistically evaluated, indicated that shifting of sex-ratio towards males remains approximately constant and that the number of individuals per family increased to 27 individuals in $T$. holothuriae and to 14 individuals in T. clodiensis in comparison with the first egg-sac of sample E. It cannot be decided, however, if the rather strong increase of individuals and the shifting of the sex-ratio towards males is maintained during the whole reproductive cycle. In order to resolve this question $4-8$ egg-sacs per female should have been examined. 
The physiological process which is at the base of the phenomenon described above cannot be explained by the present data. The findings suggest, however, an adaptive nature for such a mechanism. According to the hypothesis of sexdetermination in Tisbe where the greater proportion of males is a function of homozygosity, the high degree of females in nature would be a consequence of the high level of heterozygosity permitted by a favorable environment (Battaglia, 1964). Battaglia continues (page 459): "Even if the number of females should greatly exceed that of males, the reproductive rate of the population would not be affected, since in Tisbe, each male is able to fertilize several females." This interpretation would not apply to species such as $T$. clodiensis and $T$. dobzhanskii, since a strong decrease of males in a population-in nature or in the laboratory-would delay fertilization of most of the females to a relatively high degree; first, because $T$. clodiensis and $T$. dobzhanskii tend to mate for a relatively long time (sometimes 24 hours and longer), and, secondly, even though a male is able to fertilize several females, not all males have two spermatophores and it takes some time to produce a new spermatophore. Studies with $T$. reluctans and $T$. persimilis proved that a new spermatophore is produced after about 2 days (it is probable that there are differences between the various species). A strongly reduced male population would thus induce a delay in fertilization and as a consequence an increase of males in the following generation which should guarantee a normal fertilization of the females, as long as the delay is not too long. At this point I would like to return to a question mentioned before, i.e., the duration of the influence of overmaturation. Even if subsequent egg-sacs (3rd, 4th, etc.) showed an increase of females, their normal fertilization would be assured because of the abundance of males produced in the first two egg-sacs. These considerations so far have to be restricted to $T$. dobzhanskii, T. clodiensis, and T. holothuriae.

Another important factor in this context is certainly provided by population density. Where densities are low, the chance of females being normally fertilized are reduced. According to Battaglia (1964) inbreeding following the low population density would increase the proportion of males and thus, give a higher proportion of fertilized females.

This may be the case for species like $T$. reticulata and $T$. gracilis where inbreeding increases the proportion of males, but not for $T$. clodiensis where inbreeding has no effect on masculinization (Fava, personal communication). In this species the mechanisms of "overmaturation of eggs" may operate as a consequence of a reduced population density. It would be helpful to know if $T$. dobzhanskii is affected by inbreeding and on the other hand, if $T$. reticulata and $T$. gracilis are influenced by a delayed fertilization, in order to understand to what degree sex in Tisbe may be genetically and environmentally determined.

The author is grateful to Professor Bruno Battaglia for valuable suggestions during the preparation of this manuscript.

\section{SUMMARY}

Delay in fertilization of the females of Tisbe dobzhanskii from Anzio, T. holothuriae from Ponza, and T. clodiensis from Venice and Ponza was found to affect the sex-ratio of these populations. 
The degree of the influence depended largely upon the lateness of fertilization and, thus, upon the biology of the species.

Especially in T. dobzhanskii shifting of the sex-ratio in favor of males was highly significant. In the other populations it was less evident, but still significant. If the delay of fertilization was too great, the females were no longer able to produce viable offspring.

In addition to the shifting of the sex-ratio towards males an increase of offspring per family was observed.

The possible adaptive nature of the phenomenon is discussed.

\section{LITERATURE CITED}

Ar-Rushdi, A. H., 1958. The polygenic basis of sex-ratio in Tigriopus. Proc. Xth. Inter. Cong. Genetics, II : 8-9.

Battaglia, B., 1958. Selezione e rapporto dei sessi nel Copepode Harpacticoide Tisbe gracilis (T. Scott). Atti. Accad. Naz. Lincei Rend. Cl. Sci. Fis. Mat. Natur. Series VIII, $24: 327-335$.

Battaglia, B., 1959. Il polimorfismo adattativo e i fattori della selezione nel Copepode Tisbe reticulata Bocquet. Archo Oceanogr. Limnol., 11(3) : 19-69.

Battaglia, B., 1959a. Facteur thermique et différenciation saisonnière chez un Copépode Harpacticoide de la Lagune de Venise. Vie Milieu, 10: 1-13.

Battaglia, B., 1964. Advances and problems of ecological genetics in marine animals. Proc. XIth. Inter. Cong. Genetics, II : 451-463.

Battaglia, B., and L. Malesani, 1959. Ricerche sulla determinazione del sesso nel Copepode Tisbe gracilis (T. Scott). Boll. Zool., 26: 423-433.

Battaglia, B., and L. Malesani, 1962. Gli effetti della selezione operata in assenza di inincrocio sugli spostamenti del rapportosessi in Tisbe gracilis (Copep., Harpact.) Atti. Accad. Naz. Lincei Rend. Cl. Sci. Mat. Natur. Series VIII, 32: 251-257.

Egami, N., 1951. A note on the sex differentiation of the marine Copepod Tigriopus japonicus. Annot. Zool. Jap. 24 : 131-136.

Hertwig, G., 1921. Über den Einfluss der Überreife der Eier auf das Geschlechtsverhältnis von Fröschen und Schmetterlinger. Sitzungsberichte der Bayrischen Akademie der Wissenschaften zu Muchen, Mathematisch physikalische Klasse, 1921: 263-294.

Kuschakewitsch, S., 1923. Die Entwicklungsgeschichte der Keimdrüsen von Rana esculenta. Festschrift zum 60 Geburtstag von R. Hertwig, 2: 63-225.

Lazzaretto-Colombera, I., and G. Polo, 1969. Polimorfismo e superiorità degli eterozigoti nel Copepode Harpacticoide Tisbe clodiensis. Atti Ist. Veneto Sci. 127: 383-392.

SeIler, J., 1920. Geschlechtschromosomenuntersuchungen an Psychiden. I. Experimentelle Beeinflussung der geschlechtsbestimmenden Reifeteilungen bei Talaeporia tubulosa. Arch. Zellforsch., $15:$ 249-268.

Shull, A. F., and S. Ladoff, 1916. Factors affecting male-production in Hydatina. J. Exp. Zool., 21 : 127-161.

TAKeda, N., 1950. Experimental studies on the effect of external agencies on the sexuality of a marine Copepod. Physiol. Zool. 23 : 288-301.

Volkmann-Rocco, B., and B. Battaglia, 1971. A new case of sibling species in the genus Tisbe (Copepoda, Harpacticoida). Proc. Fifth European Symposium on Marine Biology (Piccin, Padova), in press.

Witschi, E., 1923. Ergebnisse der neueren Arbeiten über die Geschlechtsprobleme bei Amphibien. Z. Indukt. Abstamm. VererbLehre Berlin, 31: 287-312.

Witschi, E., 1924. Die Beweise für die Umwandlung weiblicher Jungfrössche in männliche nach uteriner Überreife der Eier. Wilhelm Roux Arch. Entwicklungsmech. Organismen, 102: 168-183. 


\section{$2 \mathrm{BHL}$ Biodiversity Heritage Library}

Volkmann-Rocco, Brigitte. 1972. "THE EFFECT OF DELAYED FERTILIZATION IN SOME SPECIES OF THE GENUS TISBE (COPEPODA, HARPACTICOIDA)." The Biological bulletin 142, 520-529. https://doi.org/10.2307/1540327.

View This Item Online: https://www.biodiversitylibrary.org/item/17312

DOI: https://doi.org/10.2307/1540327

Permalink: https://www.biodiversitylibrary.org/partpdf/7016

\section{Holding Institution}

MBLWHOI Library

\section{Sponsored by}

MBLWHOI Library

\section{Copyright \& Reuse}

Copyright Status: In copyright. Digitized with the permission of the rights holder.

License: http://creativecommons.org/licenses/by-nc-sa/3.0/

Rights: https://biodiversitylibrary.org/permissions

This document was created from content at the Biodiversity Heritage Library, the world's largest open access digital library for biodiversity literature and archives. Visit BHL at https://www.biodiversitylibrary.org. 